\title{
RISK MANAGEMENT OF HUMAN- AND SYSTEM-RELATED ERRORS IN THE PNEUMATIC TUBE SYSTEM OPERATION AT DR. HASAN SADIKIN GENERAL HOSPITAL BANDUNG, INDONESIA
}

\author{
Shofa Munaya ${ }^{1 *}$, Nina Tristina ${ }^{2}$, Fajar Wasilah ${ }^{2}$ \\ ${ }^{1}$ Resident of Clinical Pathology, Faculty of Medicine, Universitas Padjajaran, Bandung, \\ Indonesia. \\ ${ }^{2}$ Clinical Pathology Department, Faculty of Medicine, Universitas Padjajaran, Dr. Hasan Sadikin \\ General Hospital Bandung, Indonesia.
}

*Corresponding Author: Shofa Munaya, Resident of Clinical Pathology, Faculty of Medicine, Universitas Padjajaran. Email: munabammualim@gmail.com.

\begin{abstract}
Pneumatics is a propulsion system which makes use of pressured air. Sixty percent of hospitals utilize this system due its positive benefit in saving transportation time and accuracy. In its implementation, problems may arise from procedural errors (or human errors) and from the PTS system itself (or system error) and are to be evaluated through a risk management. We aimed to determine the occurrence of human and system errors in PTS operation, as well as the risk classification based on the risk criteria scoring at Dr. Hasan Sadikin General Hospital (RSHS) Bandung in January 2018 - December 2019. This research is a cross-sectional descriptiveretrospective observational study. Data was collected from the reports on PTS operational problems within the 2-year period at RSHS. The data was then analyzed and processed using the SPSS 17.0 software, with which we quantified the obtained qualitative data. We found 26 reports of PTS repair, $12(46.1 \%)$ of which were instrument-related (damage to vacuum, LAN, and compressor, as well as system overheat). 9 (34.6\%) repairs were resulted from tube problems (jammed or broken caps in the PTS line), 4 (15.4\%) were caused by damage to PTS pipes and line, and $1(3.9 \%)$ by damage to the supporting spare parts. The best approach of prevention is to regularly change the instrument and tubes, manually deliver the samples, better manage the PTS personnel, and provide personal protective equipment. The recorded damage to the PTS system at RSHS was entirely caused by system errors. There was also a human error aspect in the tube shipping but it was not recorded.
\end{abstract}

Keywords: Pneumatic tube system, human error, system error

\section{INTRODUCTION}

The term "pneumatic" comes from the Greek which means the "air" or "wind". Pneumatics is a system that uses energy stored in the form of compressed air to generate power. At present, such system has been widely implemented automatically (1). In 1836, William Murdoch invented the first pneumatic system used to deliver mails in London $(2,3)$.

The working mechanism of the pneumatic system is similar to the hydraulic system with the only difference being their driving force. Pneumatics utilizes air pressure as its propulsive force, 
whereas the hydraulic system uses oil. In pneumatics, the compressed air functions to drive the working cylinder which will later convert the power/ air pressure into mechanical power through the back-and-forth movement of the cylinder. This system can be applied to various fields, such as industry, banks, and hospitals, in which the dominant use is found $(60 \%)(3,4)$.

A pneumatic tube transport system, which can be either a point-to-point or multi-point system, is a tube distribution network that delivers tubes containing small quantities of objects by means of compressed air. The prime driving force is an exhauster or blower with a diverter valve that can change the direction of airflow in the tube as needed to move the tube through the system. The tube can be controlled via a diverter to ensure it reaches the designated destination. A central control system is also present to ensure the entire route functionality of the pneumatic tube (5).

The advantages of the pneumatic tubes use include better effectiveness due to its use of air, durable components, high-temperature \& dusty-environment resistant, simple design, and easy operation. The pneumatic tube is considerably safe as the components will not burn when overheated due to excessive load. It also does not cause pollution thus is safer environmentally (6).

In its specific use in hospitals, pneumatic tubes offer many benefits which include saving sample and drug transportation time, as well as more accurate so that specimen misdeliveries can be prevented. Each specimen and drug delivery using the tube has to be recorded to prevent loss of specimen. Beside the previously mentioned usefulness, the use of pneumatic tubes can reduce queues in laboratories and pharmacies. As the tube connects all zones of the hospital, it can also reduce labor (3).

On the other hand, the pneumatic tubes have some drawbacks to be taken into account. The use of air power causes changes in volume upon compression or heating, this will in turn affect the accuracy of air supply to the pneumatic tube system. Moreover, the cylinder outer and inner diameter of the system are $315 \mathrm{~mm}$ and $240 \mathrm{~mm}$, respectively. Such dimension can only allow delivery of objects with a maximum diameter of $500 \mathrm{~mm}$ and a weight of $2-4 \mathrm{~kg}$. The system also requires a processing step to ensure that the air is not contaminates with water or dust, thus the tube produces a fairly unpleasant noise $(6,7)$.

Some of other components of the pneumatic tube are compressor and blower. The compressor functions to compress the air to the desired pressure, whereas the blower is a fan that transports the tube through a vacuum pressure. Another component is a device that controls the pressure and consists of a filter, pressure regulator, lubricator, and cylinder. The cylinder, which can be of a single-acting or double-acting type, serves to circulate compressed air. A three-way diverter directs the movement of the tube in reaching its destination. In addition, a carrier or tube is used to carry specimens. PVC pipes with a diameter of 4 and 6 inches are mounted on the ceiling as the network of the pneumatic tubes. A delivery station is the place to receive and send pneumatic tubes. Lastly, a computer is also present at the pneumatic tube control center. The pneumatic system and its operational diagram are illustrated in Figure 1 and $2(5,8)$. 


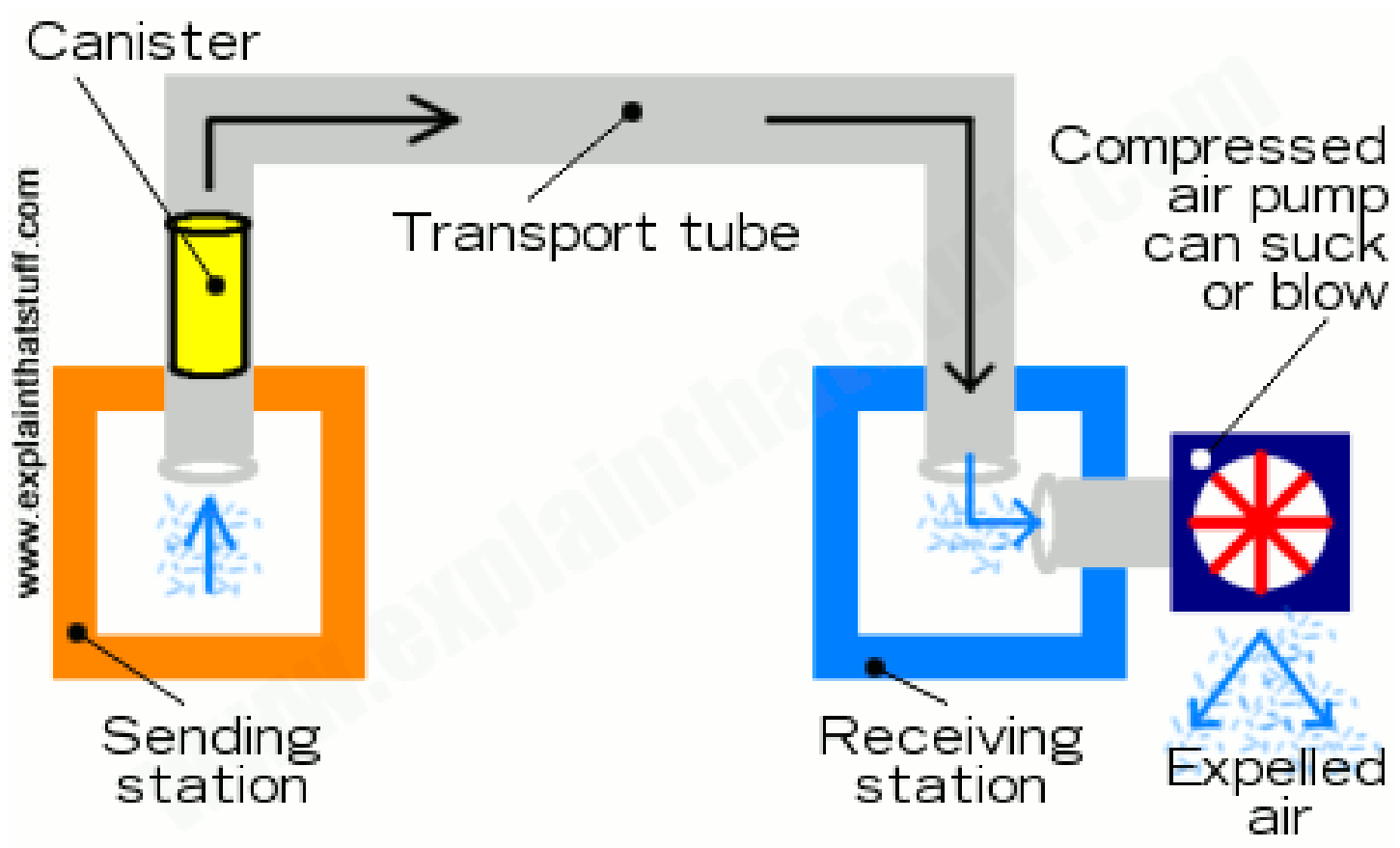

Figure 1. The pneumatic system (9).

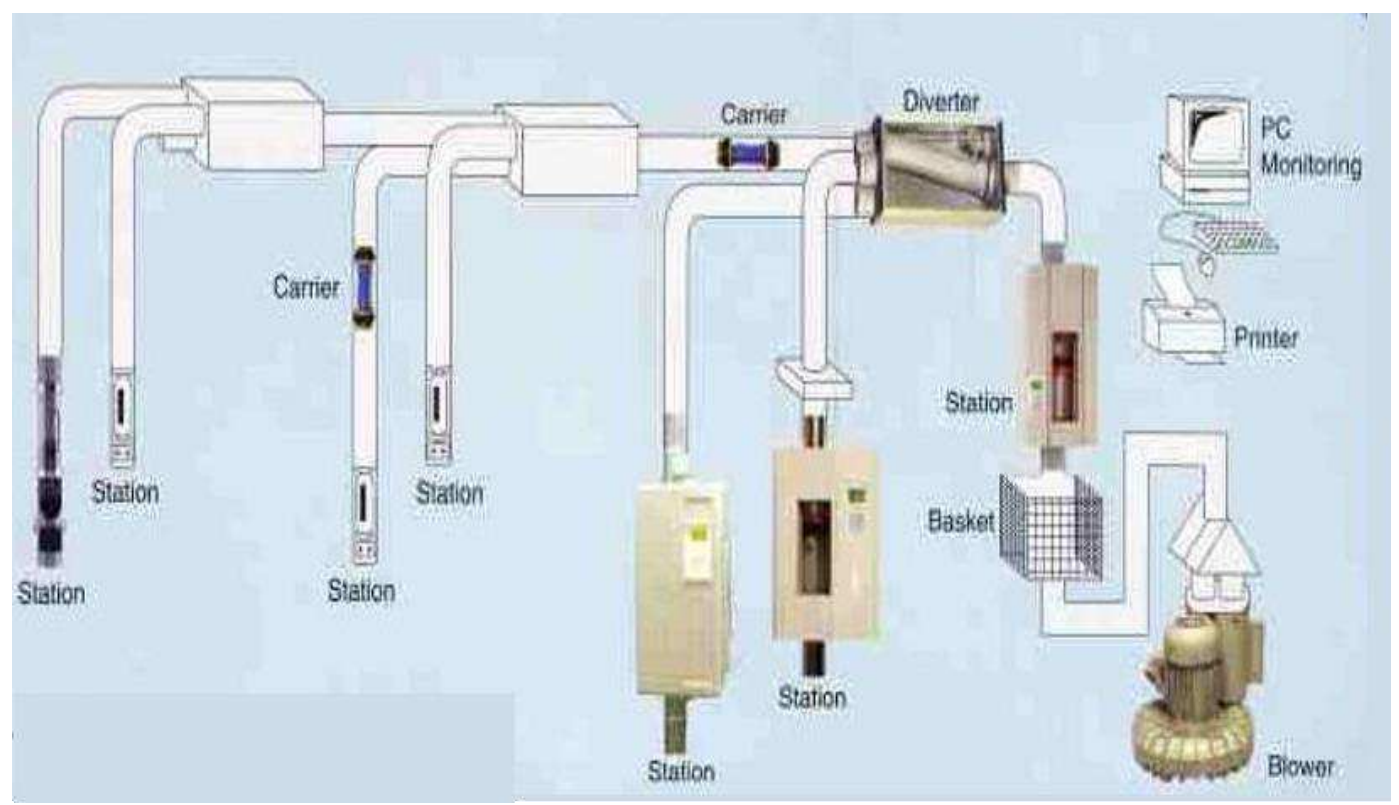

Figure 2. Operational diagram of pneumatic tube system (3).

In the day-to-day operation of the pneumatic tube, there is a high possibility of disturbances arising from procedural error (human error) or interference from the system itself (system error).

With reference to the International Organization for Standardization (ISO) 14791, risk management is defined as a systematic application of the implementation of management policies, procedures, and practices, in order to analyze, evaluate, control, and monitor risk. This process includes anticipating possible errors, assessing the frequency error occurrence, as well as the 
consequence or level of harm caused by the errors and what measure that can be done to reduce the risk of the potential hazards to an acceptable level. This following formula is used to determine risk priority $(9,10)$ :

Risk Rating $=$ Probability $\mathbf{x}$ Exposure Frequency $\mathbf{x}$ Consequence

Table 1 below shows the risk criteria scoring $(9,10)$ :

Table 1. Risk criteria scoring (10)

\begin{tabular}{|c|c|c|c|c|c|c|}
\hline \multicolumn{2}{|c|}{ Probability } & \multicolumn{5}{|c|}{ Impact } \\
\hline Rating & Score & $\begin{array}{l}\text { Personnel } \\
\text { Safety }\end{array}$ & Resources & $\begin{array}{c}\text { Work } \\
\text { Performance }\end{array}$ & $\begin{array}{l}\text { Property } \\
\text { Damage }\end{array}$ & Reputation \\
\hline No risk & 1 & No injuries & No impact & No delays & Minor & No impact \\
\hline Mild risk & 2 & $\begin{array}{l}\text { Minor } \\
\text { injuries }\end{array}$ & $\begin{array}{l}\text { Moderate } \\
\text { impact }\end{array}$ & Mild delays & Moderate & $\begin{array}{l}\text { Potential } \\
\text { damage }\end{array}$ \\
\hline $\begin{array}{c}\text { Moderate } \\
\text { risk }\end{array}$ & 3 & $\begin{array}{c}\text { Moderate to } \\
\text { life impacting } \\
\text { injuries }\end{array}$ & $\begin{array}{l}\text { Requires } \\
\text { additional } \\
\text { resources }\end{array}$ & $\begin{array}{c}\text { Significant } \\
\text { delays }\end{array}$ & Substantial & Damaged \\
\hline High risk & 4 & $\begin{array}{c}\text { Life } \\
\text { threatening } \\
\text { injuries from } \\
\text { single } \\
\text { exposure }\end{array}$ & $\begin{array}{l}\text { Requires } \\
\text { institutional } \\
\text { resources }\end{array}$ & Major delays & Severe & $\begin{array}{c}\text { Loss of } \\
\text { confidence }\end{array}$ \\
\hline
\end{tabular}

Laboratories must examine the entirety of the process to locate any flaws and the possibility of errors and hazards so that action can be taken to detect and prevent these errors before affecting the examination results. Such measure can be taken by creating a process map of the inspection process, starting from the pre-analytical, analytical, and post-analytical process and evaluating the risk of potential hazards in each (9).

Risk is a situation faced by an individual or company in which there is a possibility of harm. Risk can be estimated by combining the probability of hazard occurrence and the hazard severity (9).

Human errors are the disturbances caused by the operator's error and this definition is limited to this study. Such error can be in the form of untrained personnel and unfulfilled requirements in sending specimens through a pneumatic tube. The system error in this study is defined by the occurrence of disturbance that occurs because the instruction given cannot be recognized by the system (11). System errors include instrument-related problems (insufficient vacuum strength, damage to compressor or local area network (LAN), and system overheat), damage to circuit or delivery lines and pipes, damage to the carrier (broken and ruptured caps, as well as tubes being stuck in the delivery line), and interference in the supporting parts of the system (11). 
The objective of this study is to determine the occurrence rate of human- and system-related errors in pneumatic tube operation at Dr. Hasan Sadikin Hospital Bandung in January 2018 December 2019, to define the risk classification (human or system error) based on the risk criteria scoring.

\section{METHOD}

In the conduct of this cross-sectional retrospective-descriptive observational study, we used data of reports on pneumatic tube operational problems within 2 years from staff and service reports from January 2018 - December 2019 at Dr. Hasan Sadikin Hospital Bandung. The research was conducted at the Central Laboratory of the Clinical Pathology Laboratory Installation, Dr. Hasan Sadikin Hospital Bandung. Data was analyzed and processed using the SPSS 17.0 software, with which we quantified the qualitative data obtained.

Referring to the Management of Health and Safety at Work Regulation 1992 (MHSWR 1992) and the Control of Substances of Hazardous to Health and Regulations 1999 (COSHH 1999), the risk management analysis for the pneumatic tube system includes the suitability of the specimen to be transported, pneumatic tube design that is strong and safe from leakage, packing of specimens that is in accordance with procedures, and procedures to be carried out in the event of leakage or spilled specimens, as well as providing training, information, and complete instructions regarding the pneumatic tube system (12).

\section{RESULT}

The following result was obtained in 2018 - 2019: there were 26 pneumatic tube system (PTS) repairs, all of which were caused by system errors (interference with the device), 12 (46.1\%) of which were instrument-related (damage to the vacuum, LAN, and compressor, as well as system overheat), tube-related problems (tubes got stuck or damaged on the PTS line) occurred 9 times (34.6\%), damage to PTS pipes and line took place 4 times (15.4\%). Lastly, 1 repair (3.9\%) was in subsequent of a damage to one of the supporting parts (the plastic sheet covering the device interior).

During the same period, 33 repairs of PTS tube were also recorded: 3 (9.1\%) of which were caused by damaged or detached caps during shipping, while the reasons for the remaining 30 repairs (90.9\%) were not stated. The results of this study are as listed in Table 2 and 3 below.

Table 2. Damage to PTS system

\begin{tabular}{|c|l|l|l|c|c|}
\hline No. & Cause of Damage & \multicolumn{1}{|c|}{ Direct Impact } & Outcome & Frequency & $\begin{array}{c}\text { Duration } \\
\text { of Failure } \\
\text { (Hour) }\end{array}$ \\
\hline 1. & $\begin{array}{l}\text { Tube-related } \\
\text { problems }\end{array}$ & $\begin{array}{l}\text { Samples have to be } \\
\text { transported manually }\end{array}$ & $\begin{array}{l}\text { Extended turn- } \\
\text { around time }\end{array}$ & $9(34.6 \%)$ & $<24$ \\
\hline 2. & $\begin{array}{l}\text { Instrument-related } \\
\text { problems }\end{array}$ & $\begin{array}{l}\text { Samples have to be } \\
\text { transported manually }\end{array}$ & $\begin{array}{l}\text { Extended turn- } \\
\text { around time }\end{array}$ & $12(46.1 \%)$ & $24-48$ \\
\hline
\end{tabular}




\begin{tabular}{|c|l|l|l|c|c|}
\hline 3. & $\begin{array}{l}\text { Damage to pipes } \\
\text { and line }\end{array}$ & $\begin{array}{l}\text { Samples have to be } \\
\text { transported manually }\end{array}$ & $\begin{array}{l}\text { Extended turn- } \\
\text { around time }\end{array}$ & $4(15.4 \%)$ & $24-72$ \\
\hline 4. & $\begin{array}{l}\text { Damage to } \\
\text { supporting parts }\end{array}$ & $\begin{array}{l}\text { Samples have to be } \\
\text { transported manually }\end{array}$ & $\begin{array}{l}\text { Extended turn- } \\
\text { around time }\end{array}$ & $1(3.9 \%)$ & $24-96$ \\
\hline
\end{tabular}

Table 3. Damage to PTS tubes

\begin{tabular}{|c|l|l|l|c|c|}
\hline No. & Cause of Damage & Direct Impact & Outcome & Frequency & $\begin{array}{c}\text { Duration } \\
\text { of Failure } \\
\text { (Week) }\end{array}$ \\
\hline 1. & $\begin{array}{l}\text { Damaged/ } \\
\text { detached caps } \\
\text { upon shipping }\end{array}$ & $\begin{array}{l}\text { Tubes cannot be used } \\
\text { to transport samples }\end{array}$ & $\begin{array}{l}\text { Reduced number of } \\
\text { usable PTS tubes }\end{array}$ & $3(9.1 \%)$ & $2-3$ \\
\hline 2. & $\begin{array}{l}\text { Unlisted reason } \\
\text { for repair }\end{array}$ & $\begin{array}{l}\text { Tubes cannot be used } \\
\text { to transport samples }\end{array}$ & $\begin{array}{l}\text { Reduced number of } \\
\text { usable PTS tubes }\end{array}$ & $30(90.9 \%)$ & $2-3$ \\
\hline
\end{tabular}

\section{DISCUSSION}

The day-to-day application of PTS in hospitals encounters several obstacles, both in terms of human and system error. The result revealed that damage to PTS was entirely caused by system error as a consequence of instrument-related problems, tube-related problems, damage to tube caps, and tubes that were stuck in the PTS pipeline. Other recurring interferences were due to reduced vacuum strength thus sample transportations were not possible, system overheat thus the system had to be shut down, interference with the LAN pad and compressor, as well as objects covering the device interior (13).

Some points that should be taken into account in a risk analysis are the worst possibilities and the consequences these possibilities may bring. In PTS, the risk analysis consists of problems with the PTS tube quality and procedure for sample transportation. Frequent tube jamming is also of an inconvenience as it causes the sample to be delivered after exceeding the sample stability time limit. If this happens, sample examination cannot be carried out (sample rejected) (14).

After determining all possible issues and risks, the next most effective step would be to eliminate these issues and risks. In this case, the most interferences were instrument- and tuberelated. For this reason, the best approach is to regularly replace them with new instruments and tubes. If eliminating the problem is condemned not possible, the second step that can be taken is a substitution with harmless materials. In this case, damaged instrument or tube should not be utilized during the time being and sample deliveries should be done manually. The third measure is the engineering and administrative control: only trained laboratory personnel should be allowed to operate PTS. Lastly, if the three measures above are not feasible, is to equip personnel with appropriate personal protective equipment such as gloves, lab coat, masks, and goggles to prevent exposure to samples (15).

\section{CONCLUSION}


All recorded damage in Dr. Hasan Sadikin Hospital Bandung was caused by equipment failure (system error). While there was also an aspect of human error in the tube delivery problems, it was not recorded. The result of this study is expected to be used to determine risk management and subsequent follow-up plans.

For further research, we suggest that damage to PTS system is recorded in more detail and covers all aspects, both human and system error. We also urge the need for routine check and maintenance to ensure the tube quality. Training regarding procedures for sample delivery is imperative, specifically on how to close the tube properly and how each delivery should meet the requirement for the maximum weight and volume allowed.

\section{REFERENCES}

1. Sistem Pneumatik: Universitas Negeri Yogyakarta. (2020).

2. How Do Pneumatic Tubes Work? Aerocom USA. Retrieved 2020, from https://www.aerocomusa.com/how-do-pneumatic-tubes-work/.

3. Haider, I. (2020). Contemporary technology pneumatic tube system.

4. Pneumatic Tube System and Transport Robots | Sumetzberger. Retrieved 2020, from https://www.sumetzberger.at/en/pneumatic-tube-systems.

5. Health Facilities Scotland. (2011). Scottish Health Technical Memorandum 08-04: Specialist Services - Pneumatic Tube Transport Systems - Part A: Overview and Management Responsibilities.

6. Studies T. Pneumatic tube.

7. AC3000 Pneumatic Tube System | Aerocom USA. Retrieved 2020, from https://www.aerocomusa.com/systems/ac3000.

8. Mavaji, D. A. M. (2013). Innovative Methods To Improve Hospital Efficiency- Study Of Pneumatic Transport Systems (Pts) In Healthcare. IOSR Journal of Business and Management. https://doi.org/10.9790/487x-0961015.

9. Woodford C. Pneumatic Tube Transport 2021 [updated April 16 2021]. Available from: https://www.explainthatstuff.com/pneumatic-tube-transport.html

10. Njoroge, S. W., \& Nichols, J. H. (2014). Risk management in the clinical laboratory. In Annals of Laboratory Medicine. https://doi.org/10.3343/alm.2014.34.4.274.

11. Risk Rating \& Management | American Chemical Society. Retrieved 2020, from https://www.acs.org/content/acs/en/chemical-safety/hazardassessment/fundamentals/risk-assessment.html.

12. Senders, J., \& Moray, N. (1991). Human Error: Cause, Prediction, and Reduction. Lawrence Erlbaum Associates.

13. Health and Safety Executive. (1999). Safe use of pneumatic air tube transport systems for pathology specimens. Retrieved 2020, from https://www.hse.gov.uk/pubns/misc186.pdf.

14. RS Panti Rapih Yogyakarta. Canggih bukan berarti aman dari risiko - suatu kajian FMEA (failure mode and effect analysis) terhadap penggunaan pneumatic tube system di RS Panti Rapih Yogyakarta.

15. American Chemical Society. (2015). Identifying and evaluating hazards in research laboratories.

16. Hierarchy of Hazard Control | Graphic Products. Retrieved September 16, 2020, from https://www.graphicproducts.com/articles/hierarchy-of-hazard-control. 